\title{
First record of the exotic species Axis axis (Erxleben, 1777) (Artiodactyla, Cervidae) in the state of Santa Catarina, southern Brazil
}

\author{
Jackson F. Preuss, Eduarda Posser, Laura B. Albrecht, Victor P. R. da Silva, \\ Fernanda C. Bandiera
}

Universidade do Oeste de Santa Catarina, Departamento Ciências Agrárias, Curso de Medicina Veterinária, 89900-000, São Miguel do Oeste, SC, Brazil. Corresponding author: Jackson F. Preuss, jackson_preuss@yahoo.com.br

\begin{abstract}
In this work, we describe the first occurrence record of the exotic species of deer Axis axis (Erxleben, 1777) from natural environments of the state of Santa Catarina, southern Brazil. The study provides information about the implications of the invasion of the region's ecosystem, which is seen as a negative factor in the local community and represents a major conservation challenge.
\end{abstract}

\section{Keywords}

Deer, conservation, invasion, natural environments.

\section{Introduction}

Axis axis (Erxleben, 1777), also known as Chital or Axis Deer, is a deer species that is native to Asia (India, Nepal and Sri Lanka). This species has crepuscular habits, inhabiting a variety of field habitats but rarely dense forests (Nowak 1991). It is medium-sized, males attain a height of 80-100 cm at the shoulder and a length (excluding the tail) of $119-185 \mathrm{~cm}$; females are $67-87 \mathrm{~cm}$ in height and 114-147 cm in length (Nowak 1991; Long 2003). Adults have a reddish-brown coat with white spots (Schaller 1967). During the mating season, males have a pair of three-pointed lyre-shaped antlers (Schaller 1967; Sponchiado et al. 2011).

Deer in general are among the most intentionally introduced vertebrates on the planet (Clout and Russell 2008). Because of its highly appreciated meat and its antlers serving as trophies (Belden 1994), Axis Deer was introduced in several countries as an ornamental species, as food resource and for sport hunting (Mares and Ojeda 1984; Lever 1985; Anderson 1999).

The species was successfully introduced in Europe, Australia, Java, New Guinea, Mexico, Argentina, Uruguay, the United States, and the Andaman Islands (De Vos et al. 1956; Bentley and Downes 1968; Long 2003; Grubb 2005; Achaval et al. 2007; Romero et al. 2008; Novillo and Ojeda 2008; Fass and Weckerly 2010). In Brazil, its presence was recorded only once in areas of Pampas on the extreme west of Rio Grande do Sul in 2009 (Sponchiado et al. 2011). Since then, it has been reported by local people on the Brazilian border with Uruguay (Rosa et al. 2017), indicating an established 
population in the far south of Brazil. In this study, we describe the first record of the invasion of $A$. axis in the state of Santa Catarina, southern Brazil.

\section{Methods}

A specimen of Axis axis was found by residents and taken by soldiers of the 2nd Platoon of the 2nd Company of the 2nd Battalion of the Environmental Military Police of the state of Santa Catarina to the Núcleo de Estudos em Vida Selvagem (NEVS) of the Universidade do Oeste de Santa Catarina (UNOESC). The animal had an open fracture in the left pelvic limb and signs of acute respiratory failure. For inspection and physical examination, the individual was sedated with the use of dexmedetomidine as a pre-anesthetic medication followed by Ketamine + Midazolam for dissociative anesthesia. At 3:45 pm, the animal died due to a respiratory arrest. The animal was identified by color pattern and morphometry. It was compared with the information published by Nowak (1991) and Long (2003). We took body measurements (body length and weight). Our description of the color pattern is based on photographic records of the sample before preservation. Sex was determined by observing reproductive structures.

\section{Results}

\section{Axis axis (Erxleben, 1777)}

Figures 1, 2

New record. BRAZIL -1 adult ổ; Santa Catarina, municipality of São José do Cedro, Linha São Roque; $26^{\circ} 28^{\prime} \mathrm{S}, 053^{\circ} 30^{\prime} \mathrm{W}$; $701 \mathrm{~m}$ a.s.1.; $30 \mathrm{Aug}$. 2019; found in a rural area near the BR-163 highway; UNOESC 126/2019.

Identification. We identified the specimen as Axis axis by its external characteristics, which easily differentiate this species from other deer in the region: mediumsized deer with a height of $78 \mathrm{~cm}$ to the shoulder and a length (excluding tail) of $126 \mathrm{~cm}$; reddish-brown coat with white spots, absence of antlers; abdomen, croup, neck, inner legs, ears and tail white. Color pattern and morphometrics match the diagnosis of $A$. axis by Nowak (1991) and Long (2003).

\section{Discussion}

Our new record extends the geographic distribution of the invasive exotic species Axis axis $750 \mathrm{~km}$ north of its first and only record in southern Brazil where one male individual was recorded in 2010 at Espinilho State Park, in Rio Grande do Sul, on the border with Argentina

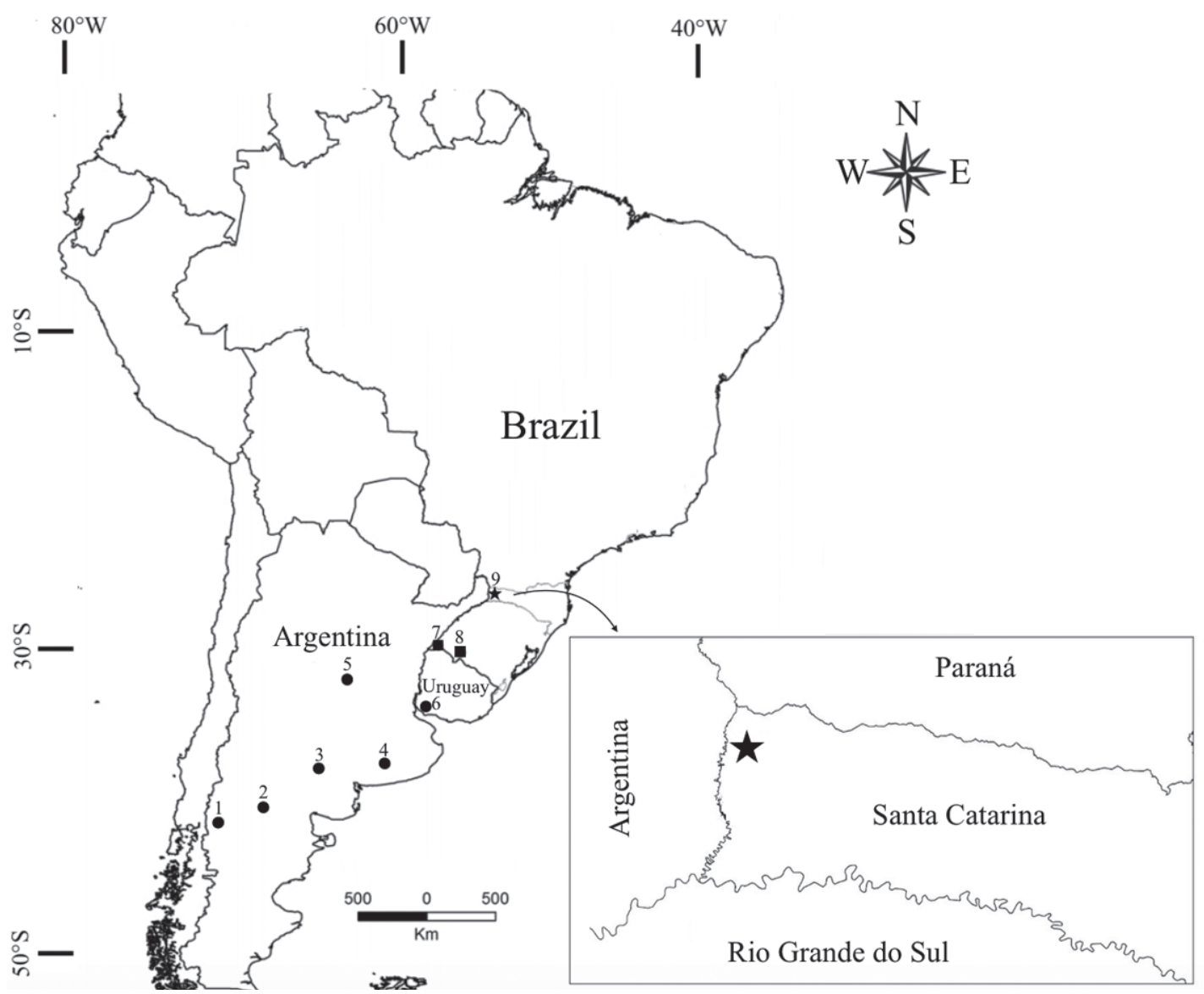

Figure 1. Localities with records of Axis axis. Circles show the localities of introduction of $A$. axis in Argentina and Uruguay. Squares show the records of $A$. axis in Rio Grande do Sul state, Brazil. Star shows the new locality in the municipality of São José do Cedro, Santa Catarina

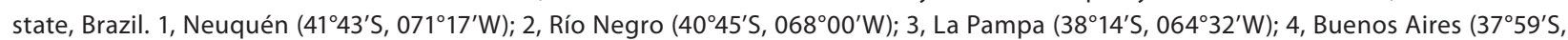
$\left.060^{\circ} 05^{\prime} \mathrm{W}\right) ; 5$, Santa Fe $\left(33^{\circ} 08^{\prime} \mathrm{S}, 062^{\circ} 57^{\prime} \mathrm{W}\right) ; 6$, Colonia $\left(34^{\circ} 01^{\prime} \mathrm{S}, 057^{\circ} 56^{\prime} \mathrm{W}\right) ; 7$, Espinilho State Park $\left(30^{\circ} 11^{\prime} \mathrm{S}, 057^{\circ} 29^{\prime} \mathrm{W}\right) ; 8^{\prime}$, Área de Proteção Ambiental de Ibirapuitã ( $\left.29^{\circ} 54^{\prime} \mathrm{S}, 055^{\circ} 45^{\prime} \mathrm{W}\right)$; and 9, São José do Cedro ( $\left.26^{\circ} 28^{\prime} \mathrm{S}, 053^{\circ} 30^{\prime} \mathrm{W}\right)$. 

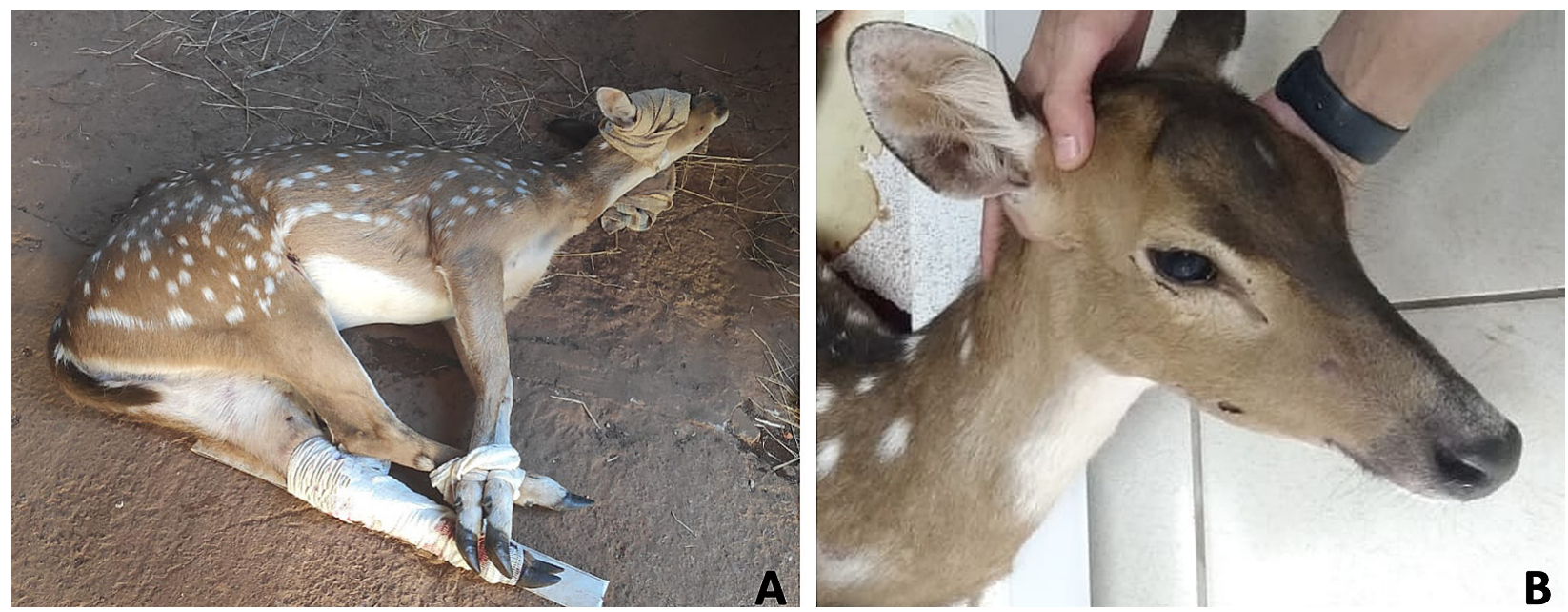

Figure 2. Axis axis (Erxleben, 1777), UNOESC 126/2019. A. Side view. B. Side view of the head.

(Sponchiado et al. 2011). However, since 2015, there have been reports by local people on the Brazilian border with Uruguay (Área de Proteção Ambiental de Ibiraiputã) of at least 30 occurrences of Axis Deer (visualizations, individuals found dead in crops and poached animals) that have been confirmed by photographs (Rosa et al. 2017; T. Reis personal communication).

Our new record was collected in a rural area near BR-163 in Santa Catarina and within the Atlantic Forest biome. The site of the record is about $20 \mathrm{~km}$ from the province of Misiones, Argentina, and this individual may have come from Argentina, as the species has recently expanded northward in that country, bringing it closer to the border with Brazil (Novillo and Ojeda 2008). In Argentina (Fig. 1), A. axis was introduced in the province of La Pampa in 1906 (Lever 1985), in the province of Buenos Aires in 1930 (Navas 1987), and later in Santa Fé, Neuquén, and Rio Negro (Petrides 1975). This species has become established in the wild in Argentina, and populations have been expanding their distribution across the country (Sponchiado et al. 2011).

It is believed that this animal may have been hit by a vehicle, as it was rescued near the BR-163 highway and had an open fracture in the left pelvic limb and multiple rib fractures with the presence of subcutaneous emphysema. Axis Deer easily gets used to human presence in both invaded and original areas, which is why herds are often seen in open areas close to houses and even use camping areas to spend the night, possibly due to greater safety from predators that avoid such areas (Duckworth et al. 2015), but this species can also use habitats with dense cover (Putman 1988; Mungall and Sheffield 1994; Demarais et al. 1998; Geist 1998; Long 2003).

The occurrence of the Axis Deer can be considered as negative impact on the ecosystem and local species (Sponchiado et al. 2011). Studies have indicated potential negative impacts on a variety of plant and animal species (Davis et al. 2016). The species is known to compete with native deer, because its physical characteristics and food habitats are similar (Etges 2016). For example, the effect of competitive exclusion generated by the size difference
(Dolman and Wäber 2008) and the aggressions between species (Bartoš et al. 1996; Stephens et al. 2003) can pose a threat to the Red Deer (Ozotoceros bezoarticus Linnaeus, 1758) in southern Brazil (Achaval et al. 2007; Machado et al. 2008; Sponchiado et al. 2011). According to Faas and Weckerly (2010), if the population density of Axis Deer increases, wild species will be displaced from high-quality habitats to lower-quality habitats, and the abundance of native deer in this region may consequently decrease. The most significant impacts are likely to occur through direct effects of modification of vegetation through herbivory, with potentially cascading indirect effects on fauna, such as transmission of diseases to wild and domestic animals, which can cause declines of rare and threatened species due to habitat modification (Faas and Weckerly 2010; Flueck 2010; Kumschick et al. 2011; Mohanty et al. 2016; Davis et al. 2016; Rosa et al. 2017).

Continuing systematic studies in the long term is necessary to assess whether populations of $A$. axis have already existed in this region. These data may support alternatives for the management of the axis deer, aiming at the conservation of regional biodiversity.

\section{Acknowledgements}

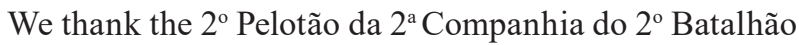
de Polícia Militar Ambiental do Estado de Santa Catarina for providing access to the animal.

\section{Authors' Contributions}

JFP photographed, identified, described or standardized the colors and the sample morphometry. FCB performed clinical care. All the authors were involved in the writing, edition, and improvement of the manuscript's final draft.

\section{References}

Achaval F, Clara M, Olmos A (2007) Mamíferos de la República Oriental del Uruguay. Segunda edición. Zonalibro Industria Gráfica, Montevideo, $216 \mathrm{pp}$. 
Anderson SB (1999) Axis deer overview and profile. http://www.hear. org/hnis/reports/hnis-axiaxiv01.pdf. Accessed on: 2020-4-14.

Bartoš L, Vaňková D, Šiler J, Losos S (1996) Fallow deer tactic to compete over food with red deer. Aggressive Behavior 22 (5): 375-385. https://doi.org/dbn7cw

Belden RC (1994) Review of exotic ungulates. A case study in Florida. Proceedings of the Annual Conference Southeastern Association of Fish and Wild Agencies 48: 78-87.

Bentley A, Downes MC (1968) Deer in new guinea part 1: notes on the field identification of certain deer species likely to be encountered in Papua and New Guinea. Papua New Guinea Agriculture Journal 20: 1-14.

Clout MN, Russell JC (2008) The invasion ecology of mammals: A global perspective. European Journal of Wildlife Research 35 (3):180-184. https://doi.org/10.1071/wr07091

Davis NE, Bennett A, Forsyth DM, Bowman DMJS, Lefroy EC, Wood SW, Woolnough AP, West P, Hampton JO, Johnson CN (2016) A systematic review of the impacts and management of introduced deer (family Cervidae) in Australia. Wildlife Research 43 (6): 515-532. https://doi.org/10.1071/wr16148

De Vos A, Manville RH, Van Gelder RG (1956) Introduced Mammals and their influence on native biota., 1st edition. New York Zoological Society, New York, 32 pp.

Demarais S, Baccus JT, Traweek MS Jr (1998) Non-indigenous ungulates in Texas: long-term population trends and possible competitive mechanisms. Transactions North American Wildlife Natural Resource Conference 63: 49-55.

Dolman PM, Wäber K (2008) Ecosystem and competition impacts of introduced deer. European Journal of Wildlife Research 35 (3): 202-214. https://doi.org/10.1071/wr07114

Duckworth JW, Kuma NS, Anwarul Islam M, Sagar Baral H, Timmins R (2015) Axis axis. The IUCN Red List of Threatened Species 2015: e.T41783A22158006. https://doi.org/10.2305/iucn.uk.20154.rlts.t41783A22158006.en Accessed on: 2020-2-27.

Etges MF (2016) Axis axis em foco: efeitos da introdução e modelagem da invasão.. Master thesis, Porto Alegre, 64 pp. https://www. lume.ufrgs.br/handle/10183/150711. Accessed on: 2020-2-12.

Faas CJ, Weckerly FW (2010) Habitat interference by Axis Deer on White-Tailed Deer. Journal of Wildlife Management 74 (4): 698 706. https://doi.org/10.2193/2009-135

Flueck WT (2010) Exotic deer in southern Latin America: what do we know about impacts on native deer and on ecosystems? Biological Invasions 12: 1909-1922. https://doi.org/10.1007/s10530009-9618-x

Geist V (1998) Deer of the world. Stackpole, Mechanicsburg, Pennsylvania, USA, $421 \mathrm{pp}$.

Grubb P (2005) Order Artiodactyla. In: Wilson DE, Reeder DM (Eds) Mammal species of the world. A taxonomic and geographic reference. 3rd edition. Johns Hopkins University Press, Baltimore, 637-722.

Kumschick S, Alba C, Hufbauer RA, Nentwig W (2011) Weak or strong invaders? A comparison of impact between the native and invaded ranges of mammals and birds alien to Europe. Diversity and Distribution 17 (4): 663-672. https://doi.org/10.1111/j.1472-46 42.2011.00775.x

Lever C (1985) Naturalized mammals of the world. Longman, London, $487 \mathrm{pp}$.

Long JL (2003) Introduced mammals of the world. Their history, distribution and influence. CSIRO Publishing, Victoria, $589 \mathrm{pp}$.

Machado AB, Drummond GM, Paglia AP (2008) Livro Vermelho da Fauna Brasileira Ameaçada de Extinção. Ministério do Meio Ambiente, Brasília, 1420 pp.

Mares MA, Ojeda RA (1984). Faunal commercialization and conservation in South America. BioScience 34 (9): 580-584. https://doi. org/10.2307/1309601

Mohanty NP, Harikrishnan S, Sivakumar K, Vasudevan K (2016) Impact of invasive spotted deer (Axis axis) on tropical island lizard communities in the Andaman archipelago. Biological Invasions 18 (1): 9-15. https://doi.org/10.1007/s10530-015-1006-0

Mungall EC, Sheffield WJ (1994) Exotics on the range: the Texas example. Texas A\&M University, College Station, USA, 265 pp.

Navas JR (1987) Los vertebrados exóticos introducidos en la Argentina. Revista del Museo Argentino de Ciencias Naturales "Bernardino Rivadavia” e Instituto Nacional de Investigación de las Ciências Natulales, Zoología 14 (2): 7-38.

Novillo A, Ojeda RA (2008) The exotic mammals of Argentina. Biological Invasions 10 (8): 1333-1344. https://doi.org/10.1007/s10530007-9208-8

Nowak RM (1991) Walker's mammals of the world. 5th edition. John Hopkins University Press, Baltimore, 1629 pp.

Petrides GA (1975) The importation of wild ungulates into Latin America, with remarks on their environmental effects. Environmental Conservation 2 (1): 47-51. https://doi.org/10.1017/S037689 2900000667

Putman R (1988) The natural history of deer. Cornell University Press, Ithaca, New York, USA, $191 \mathrm{pp.}$

Romero JÁ, Medellín RA, Ita AO, Silva HG, Sánchez Ó (2008) Animales exóticos en México: Una amenaza para la biodiversidad., 1st edn. Semarnat, México, 518 pp.

Rosa CA, Curi NHA, Puertas F, Passamani M (2017) Alien terrestrial mammals in Brazil: current status and management. Biological Invasions 19: 2101-2123. https://doi.org/10.1007/s10530-0171423-3

Schaller GB (1967) The deer and the tiger. A study of wildlife in India. The University of Chicago Press, Chicago, 384 pp.

Sponchiado J, Melo GL, Cáceres NC (2011) First record of the invasive alien species Axis axis (Erxleben,1777) (Artiodactyla: Cervidae) in Brasil. Biota Neotropica 11 (3): 403-406. https://doi.org/10.15 90/S1676-06032011000300032

Stephens RM, Alldredge AW, Phillips GE (2003) Aggressive interactions of Rocky Mountain Elk, Cervus elaphus nelsoni, during the calving season toward Mule Deer, Odocoileus hemionus, in central Colorado. Canadian Field-Naturalist 117 (2): 316-317. https:// doi.org/10.22621/cfn.v117i2.807 